\title{
Competent approach to the development of innovation entrepreneurship in the region
}

\author{
Anton Byankin \\ Komsomolsk-on-Amur state University, \\ Faculty of Economics and management \\ Komsomolsk-on-Amur, Russia \\ anton.byankin@yandex.ru
}

\author{
Galina Burdakova \\ Komsomolsk-on-Amur state University, \\ Faculty of Economics and management \\ Komsomolsk-on-Amur, Russia \\ galinabu@rambler.ru
}

\author{
Olga Chistyakova \\ Baikal State University \\ Department of Economics of Enterprises and Entrepreneurship \\ Irkutsk, Russia \\ chistyakovaov@mail.ru
}

\begin{abstract}
Improvement of the Russian economy competitiveness is being solved through the creation of regional innovation centers and clusters. In the Far East, territories of advanced social and economic development (TASED) are being created. At the same time, the role of the centers for innovative, technological and social development of the regions is assigned to higher education institutions. The entrepreneurial activity is added to the traditional activities of the University (educational and scientific), which is aimed at the commercialization of scientific and technological developments. The University becomes not only a "forge" of the personnel for the national economy but also should be the "site" for the development of innovation-oriented entrepreneurship. The objectives of the University should be to create a favorable environment and conditions for the implementation of scientific activities, creating an effective infrastructure for research, involving the student community in the conduct of fundamental and applied research, commercialization of innovations. Moreover, the goal of intellectual scientific activity should be not only the result, embodied in the form of new knowledge, prototype, etc., but also innovations in the market, focused on consumers who provide income. This new role of universities requires the modernization of the educational process as well as of the curricula and training programs for students. The purpose of the research is the analysis of competencies that are formed in students in the process of educational activities and aimed at the development of innovation entrepreneurship in the region. The authors consider the essence and stages of innovation entrepreneurship. On the basis of studying various curricula in the Komsomolsk-on-Amur state University the problems of training bachelors and masters in this field are defined. The developed analysis algorithm can be used in the universities to justify the need for additional training of students for the development of innovation entrepreneurship. The recommendations for improving the training of students, consisting in the development of comprehensive programs of the optional disciplines and project-oriented training of engineering students are worked out. The directions of further research are related to the identification of factors hindering the development of innovation entrepreneurial activity among students and
\end{abstract}

determining the needs for students to obtain specific knowledge and skills necessary for conducting innovation entrepreneurial activity.

Keywords - territory of advanced development, higher education institution, scientific and technical development, innovation and entrepreneurial activity, professional competence, professional activities

\section{INTRODUCTION}

In modern conditions the support for innovation is one of the main trends of the state regulation of the economy. At the same time, the role of the research sector is becoming more and more ambitious [1]

The problem of the innovation development of regions with the active participation of the higher education institutions initially acted as the subject of foreign authors' research, Russian scientists became engaged in it much later. Since the 1990s, the world scientific and expert community has been actively promoting the concept of national innovation systems (NIS) as a generator of industrial progress and competitiveness of countries. The NIS concept was developed by a large group of authors in the 1980s. The leaders were: B. Lundwall (Sweden), K. Freeman (UK), R. Nelson (USA). Its main ideas are the following: the main factors of economic dynamics are innovations and scientific research (Schumpeter's ideas); knowledge plays a special role in the economic development [2].

Together with the development of the national innovation systems, the approach to the role and objectives of the higher education institutions have changed. The modern Concept of "the entrepreneurial University", which combines the classical model of the University with the culture of entrepreneurship, innovation and technology transfer, was described by B. Clark [3]. The experience of the best research universities shows that 
they have a closed cycle from the education and research to the creation of small innovation enterprises; there is a new task - it is not so much personnel training, but the production of innovative ideas and personnel who develop and implement them. According to Henry Etzkowitz, entrepreneurial universities are one of the pillars of the "triple helix": the state - the business - the University [4].

The concept of "the entrepreneurial University" serves as a basis for partnership between the state, business and academic sphere. Its basic idea is that entrepreneurship should become the basic principle of the organization of universities [5]. And for this purpose it is necessary to provide appropriate training for future innovative entrepreneurs.

The government of the country, wishing to accelerate the creation of regional innovation systems, creates special economic zones with a special legal regime for entrepreneurship. Thus, the territories of advanced social and economic development (TASED) are being created in the Far East of Russia. The most high-tech area of the Khabarovsk Krai is TASED "Komsomolsk". A modern, dynamic, technological and engineering center of national scale is being created here [6]. Komsomolsk-on-Amur state University plays a significant role in the development of this TASED; it plays a leading role in innovation activity of the region. The strategic goal of the Komsomolsk-on-Amur state University is to become a resource center for economic development, innovation entrepreneurship and socio-cultural environment of the region [7].

On the basis of the University, by commercialization of scientific and technical developments, small innovative enterprises (SIE) are created. However, not all of them are sustainable; many of the problems are related to the lack of innovative entrepreneurs with the knowledge and skills of solving the problems at each stage of innovation and entrepreneurial activity.

The purpose of this study is to analyze the competences that are formed in students in the process of educational activities and aimed at the development of innovative entrepreneurship in the region. The relevance of the topic is due to the implementation of the general context of the development of professional engineering education in the Khabarovsk Krai: "idea - design - implementation management" [8].

\section{MAterials AND Methods (Model)}

The issues of the personnel training for innovative entrepreneurship are reflected in the discussions on the pages of scientific and journalistic literature. The following issues are considered: problems of development of entrepreneurship in scientific-technical sphere of Russia (O.P. Molchanova), staffing of small business within the innovative infrastructure of the University complexes (E.V. Baturina, A.M. Shestoperov), training of innovative entrepreneurship in the system of continuous professional education (R.S. Safin), problems of training specialists in the field of innovative entrepreneurship (V.A. Dubolazov, N. V. Neelova), involvement of Russian students in modern innovative entrepreneurship (I.V. Korchagina, K.V. Rogova) [9-12].
Based on the study of research papers on this subject, it was concluded that more attention was focused on the formation of competencies of entrepreneurs and methods of entrepreneurship education. At the same time, there is no specific algorithm for substantiating the necessary competencies at all stages of innovation and entrepreneurial activity (IEA).

The innovation vector of the development of the society determines the emergence of high requirements for the quality of formation of a wide range of technological skills, as well as specific economic knowledge [13, 21]. Innovation activity begins in scientific institutions that create profitable production ideas, which are the basis for innovation projects [14]. Universities become centers generating technologies and new forms of entrepreneurship. A graduate of the University is required not only to be a professional in any field of knowledge, but also to be ready to actively participate in the economic development of the society [15].

In the concept of the state priority project "Universities as centers of innovation creation space" it is stated that at least 100 University centers of innovation, technological and social development of regions will have been created by 2025. On the basis of these centers, it is planned to implement projectoriented education programs, involving the team implementation of full-life cycle projects, as well as master's programs in technological entrepreneurship [16].

Innovation and entrepreneurship can be represented in two cycles and a number of stages. Each stage of the cycle is characterized by a set of key tasks (table 1 ).

With the aim of identifying competencies that are formed in students in the process of educational activities and necessary for the conduct of innovative entrepreneurship, the analysis was conducted of the curricula of the Komsomolskon-Amur state University. We investigated the availability of the appropriate types of professional activity (TPA) and professional competences (PC). In the course of the research the curricula of 13 bachelor's and 9 master's engineering training programs (with different majors) were analyzed [17]. The comparative analysis for bachelors was carried out on the first cycle of IEA connected with the creation and development of production of innovation production (works, services).

The results of the analysis in some training programs are presented in table 2. In general, it was found that the curricula for the "scientific-research work" (SRW) phase included relevant professional activities. Graduates of $80 \%$ of the considered training programs are prepared for them. For the stages of "EDW and TPP" the curricula also provide activities for all training programs, except for 01.03.02 "Applied mathematics and computer science". It can be concluded that the University has created the preconditions for the formation of students' essential competencies, involving them in conducting fundamental and applied scientific-research works, design-engineering activities. 
TABLE I. ESSENCE AND OBJECTIVES OF THE STAGES OF THE INNOVATION AND ENTREPRENEURIAL ACTIVITY

\begin{tabular}{|c|c|}
\hline Cycles and stages & $\begin{array}{l}\text { Key challenges to be addressed during the } \\
\text { phase }\end{array}$ \\
\hline \multicolumn{2}{|c|}{$\begin{array}{c}\text { Cycle } 1 \text { "Creation and production of innovative products (works, } \\
\text { services)" }\end{array}$} \\
\hline $\begin{array}{l}\text { Scientific research } \\
\text { work (SRW) }\end{array}$ & $\begin{array}{l}\text { The collection and analysis of information; } \\
\text { organization and conduct of scientific } \\
\text { research work(SRW) using modern } \\
\text { analytical methods. }\end{array}$ \\
\hline $\begin{array}{l}\text { Experimental design } \\
\text { works and } \\
\text { technological } \\
\text { preparation of } \\
\text { production } \\
\text { (EDW and TPP) }\end{array}$ & $\begin{array}{l}\text { The development of the prototype, the } \\
\text { production technology (of implementation) } \\
\text { innovations in production and technological } \\
\text { activity; rationale and design calculation and } \\
\text { manufacturing technology innovations; } \\
\text { documentation of the stages of EDW and } \\
\text { TPP. }\end{array}$ \\
\hline $\begin{array}{c}\text { Preliminary } \\
\text { market analysis and } \\
\text { business planning } \\
\text { (PMA and BP) }\end{array}$ & $\begin{array}{l}\text { Analysis of the market situation; business } \\
\text { planning for the creation and development of } \\
\text { new organizations (activities, products); } \\
\text { investment analysis and risk identification. }\end{array}$ \\
\hline $\begin{array}{l}\text { Creation of SIE (small } \\
\text { innovative enterprises) } \\
\text { and the development of } \\
\text { production } \\
\text { (SIE and DP) }\end{array}$ & $\begin{array}{l}\text { Implementation of the business plan and } \\
\text { development of production; organization and } \\
\text { conduct of business; organization and } \\
\text { maintenance of relations with business } \\
\text { partners and consumers; execution of works } \\
\text { on the project in accordance with the } \\
\text { requirements. }\end{array}$ \\
\hline \multicolumn{2}{|c|}{$\begin{array}{c}\text { Cycle } 2 \text { "Marketing activities (introduction of products (works, } \\
\text { services) to the market and its promotion)" }\end{array}$} \\
\hline $\begin{array}{l}\text { Market analysis } \\
\text { at the stage of } \\
\text { promotion } \\
\text { products (MA) }\end{array}$ & $\begin{array}{l}\text { Market research; assessment of the impact of } \\
\text { the environment; analysis of consumer } \\
\text { behavior and demand formation. }\end{array}$ \\
\hline $\begin{array}{l}\text { Formation of a } \\
\text { marketing plan for the } \\
\text { promotion of a new } \\
\text { product (FMP) }\end{array}$ & $\begin{array}{l}\text { Development of a marketing program to } \\
\text { promote new products in the market; } \\
\text { organization of sales; advertising; } \\
\text { development of pricing policy and sales } \\
\text { promotion; PR. }\end{array}$ \\
\hline
\end{tabular}

At the same time, in the curricula of most training programs there is no production and technological activity, which complicates the process for the innovators mastering the production of scientific developments.

The development of competencies related to the solution of problems at the stages of "Preliminary market analysis and business planning" and "Creation of a small innovative enterprise and development of production" is possible within the organizational and managerial type of professional activity, it is provided by the Federal State Educational Standard (FSES). But only one of the training programs considered - 27.03.05 "Innovation" - provides for its implementation in the curriculum.

Further, a detailed analysis of the compliance of the competences regulated by the FSES with the tasks to be solved at the initial stages of the IEA was carried out.

So, for example, for the bachelor degree training program 15.03.03 "Applied mechanics" with the major in "Computational mechanics and computer engineering" it was revealed that at the stage of "SRW" the curriculum provides for the formation of competence of PC-1-6. The objectives of the IEA are resolved in full. At the stage of "OCD and CCI" provides for the formation of appropriate competencies. But the problems are solved in part, due to the lack of design and engineering activities in the curriculum areas of training.

At the stages of the "PMA and BP" and "SIE and DP" the necessary competences to be developed are not stated. Students gain knowledge through the formation of a general cultural competence - OK-3 - the ability to use the basics of economic knowledge; and general professional competence GPC-1 - the ability to use the basics of economic knowledge in assessing the effectiveness of the results of professional activities. The problems are practically not solved. Issues that provide an objective and complete picture of the current market situation, the future state of business in the external environment, the investment attractiveness of the business project and the risks of its implementation, and the organization of entrepreneurial activity are not touched upon.

It is necessary to note that it is for this purpose that the FSES provides for the possible development of innovation activities, within the competence of the PC-29 - readiness to participate in the implementation and maintenance of the results of scientific, technical and design developments in the real sector of the economy. However, this possibility is not used.

For the most appropriate area of training, where it is possible to organize innovative entrepreneurship - 27.03.05 "Innovation" (major "Innovation management"), it was found

TABLE II. ACTIVITIES REGULATED BY the FSES AND MEETING THE OBJECTIVES OF the IEA

\begin{tabular}{|c|c|c|c|c|}
\hline \multirow{2}{*}{$\begin{array}{l}\text { Stages and steps of } \\
\text { IEA }\end{array}$} & \multicolumn{4}{|c|}{ Cycle 1. "Creation and development of production of innovative products (works, services)» } \\
\hline & SRW & EDW and TPP & PMA and BP & SIE and DP \\
\hline Training programs & \multicolumn{4}{|c|}{ The presence of types of activity and PC in the curriculum of bachelors training programs } \\
\hline \multirow{2}{*}{$\begin{array}{c}09.03 .03 \text { "Applied } \\
\text { Informatics"- - Applied } \\
\text { Informatics in Economics". }\end{array}$} & \multirow{2}{*}{$\begin{array}{l}\text { Scientific research } \\
\quad(\mathrm{PC} 23-24) .\end{array}$} & \multirow{2}{*}{$\begin{array}{l}\text { Project } \\
(\text { PC 1-9). }\end{array}$} & \multicolumn{2}{|c|}{ Organizational and managerial (ПК 17-19) *. } \\
\hline & & & $\begin{array}{c}\text { Analytical } \\
(P C 20-22) * .\end{array}$ & \\
\hline \multirow{2}{*}{$\begin{array}{c}11.03 .04 \text { "Electronics and } \\
\text { nanoelectronics" - "Industrial } \\
\text { electronics". }\end{array}$} & \multirow[t]{2}{*}{$\begin{array}{l}\text { Scientific research } \\
\quad \text { (PC 1-3). }\end{array}$} & $\begin{array}{c}\text { Design and engineering } \\
\text { (PC-4 -7). }\end{array}$ & \multirow{2}{*}{\multicolumn{2}{|c|}{$\begin{array}{l}\text { Organizational and managerial } \\
\qquad(P C 10-12) *\end{array}$}} \\
\hline & & Industrial-technological (PC 8-9)*. & & \\
\hline \multirow{2}{*}{$\begin{array}{c}12.03 .04 \text { "Biotechnical } \\
\text { systems and technologies" - } \\
\text { "Engineering in biomedical } \\
\text { practice". }\end{array}$} & \multirow{2}{*}{$\begin{array}{l}\text { Scientific research } \\
\text { (PC 1-3). }\end{array}$} & Design and engineering(PC 18-22). & \multirow{2}{*}{\multicolumn{2}{|c|}{$\begin{array}{l}\text { Organizational and managerial } \\
\qquad(P C 12-14) *\end{array}$}} \\
\hline & & Industrial-technological (PC-4-11) *. & & \\
\hline \multirow{2}{*}{$\begin{array}{c}\text { 15.03.03 "Applied } \\
\text { mechanics" - } \\
\text { "Computational mechanics } \\
\text { and computer engineering". }\end{array}$} & \multicolumn{2}{|c|}{$\begin{array}{l}\text { Experimental research with the elements of scientific research } \\
\text { activity (PC 7-10). }\end{array}$} & \multicolumn{2}{|c|}{$\begin{array}{l}\text { Organizational and managerial } \\
\quad(P C 22-24, P C-27-28) *\end{array}$} \\
\hline & $\begin{array}{l}\text { Scientific research } \\
\quad(\mathrm{PC}-1-6) .\end{array}$ & $\begin{array}{c}\text { Design and engineering } \\
(P C 11-13) * \\
\text { Industrial-technological } \\
(P C-14-21) * .\end{array}$ & & $\begin{array}{l}\text { Innovative } \\
(P C-29) * \text {. }\end{array}$ \\
\hline \multirow{2}{*}{$\begin{array}{c}\text { 23.03.01 "Technology of } \\
\text { transport processes" - } \\
\text { "organization of } \\
\text { transportations". }\end{array}$} & \multirow{2}{*}{$\begin{array}{l}\text { Experimental } \\
\text { research } \\
(P C-22-28) *\end{array}$} & \multicolumn{2}{|c|}{ Measurement and design (PC-14- 21). } & \\
\hline & & $\begin{array}{l}\text { Industrial-technological } \\
\quad(P C-1-13) *\end{array}$ & \multicolumn{2}{|c|}{$\begin{array}{l}\text { Organizational and managerial } \\
\qquad(P C 29-34, P C-36) *\end{array}$} \\
\hline $\begin{array}{l}\text { 27.03.05 "Innovation"- } \\
\text { "Innovation managemen"". }\end{array}$ & $\begin{array}{l}\text { Experimental } \\
\text { research } \\
(P C-8-10) *\end{array}$ & $\begin{array}{l}\text { Industrial-technological } \\
(\Pi K-1) \text {. } \\
\text { Design and engineering } \\
\text { (PC 12 - 15). }\end{array}$ & \multicolumn{2}{|c|}{$\begin{array}{l}\text { Organizational and managerial } \\
\text { (PC 4-7). }\end{array}$} \\
\hline
\end{tabular}


curriculum did not even provide for experimental research type of professional activity, necessary for SRW. As a result, students do not form the competencies necessary for carrying out fundamental and applied works.

Analysis of master's curricula (conducted for all cycles and stages of the IEA) showed that for the stage of "SRW" appropriate types of professional activities were provided in training programs. At the same time, to a much lesser extent, masters acquire competence in the field of design preparation of production (only three master's degree programs of 9 are provided). This seems logical, since these competencies were formed at the undergraduate level. And the FSES provides an opportunity, within the framework of organizational and technological activities, to develop skills of "preliminary market analysis and business planning", as well as "creating SIE". However, this possibility is fixed in less than half of the master's degree training programs.

The situation is not conducive to, and perhaps hinders student initiatives in the creation and successful implementation of innovation business activities. The directions to improve the training of students for the development of student production and technological entrepreneurship at the University can be:

* Modernization of the implemented basic educational programs, providing for the inclusion of the necessary projectoriented modules in the optional part of the curriculum training.

* Creation of a "project office" as a part of the educational and methodological department, the scope of which will include the formation of a list of relevant practical cases, planning the necessary financial and material resources, scheduling the work of student teams on projects in laboratories that make up the innovation infrastructure of the University [7].

* Development and implementation of optional courses. The task of which will be to deepen and broaden theoretical and practical knowledge and skills of professional activities of students, introducing them to the research work, establishment of conditions for comprehensive development of the competencies required at all stages of the innovationentrepreneurial activities to fill the lack of knowledge and skills at all stages of the innovation and entrepreneurial activities.

Particular attention should be paid to the formation of competencies in the organizational and managerial activities of engineering areas of both undergraduate and graduate students.

The future graduate entrepreneur, along with professional competencies in the fields of technology and technology, should have knowledge, skills in the fields of marketing, management, entrepreneurship and other economic and managerial disciplines.
Educational activities can also include special courses on innovation entrepreneurship, business games, seminars, competitions, projects, etc. these measures will help to ensure that students will no longer perceive the innovation as entrepreneurship is not available to them the scope of activities [18].

Internal dynamics and competitiveness of these educational forms can be ensured by competitions of student business plans, participation in which allows students to test their ideas and get feedback from experts and experienced entrepreneurs [19].

One of the areas of development may be the creation of a youth school "from idea to knowledge-based business", training at all stages of the project life cycle [20], providing support at the stages of "from idea to project", "from project to technology", from technology to innovation entrepreneurship".

\section{RESULTS AND DISCUSSION}

A. It is determined that the issues of development of innovation entrepreneurship in TASED "Komsomolsk" acquire special relevance and practical significance.

B. The new role of the University in the region of advanced development, in which the University is considered a center of regional development, ensuring the integration of educational, research and innovation activities in the educational process, is stated.

C. It is revealed that the curricula implemented in the University do not form the complete list of competencies necessary for implementation of all objectives on the stages of the innovation and entrepreneurial activities.

D. The directions of improvement of training of students for the development of innovation entrepreneurship, including the project-oriented training of students majoring in engineering at the stages "from idea to project", "from project to implementation", "from implementation to management" are offered.

\section{CONCLUSION}

The development of regional innovation systems in the Far East of Russia takes place with the active state support, including the creation of territories of advanced development. The Universities are playing an increasing role in this process. In order to achieve a tangible result in the development of innovation entrepreneurship in the region, it is necessary to provide appropriate training for future innovation entrepreneurs.

As a result of the comparative analysis it was revealed that the existing training programs of students did not meet the challenges at all stages of innovation and entrepreneurship. The formation of the necessary competencies for the purposes of innovation entrepreneurship is fragmented, and, therefore, hinders the initiatorship of the University graduates in the organization of their own business. 
For the solution of problems in the sphere of students' training the actions allowing to liquidate "gaps" in formation of necessary competences were offered.

\section{Acknowledgment}

The authors express their gratitude to the Russian Foundation for Basic Research for providing financial support for the project № 17-02-00285, "Substantiation and development of the concept of innovation entrepreneurship development in the territory of advanced development on the basis of higher education institution (by the example of TASED "Komsomolsk")".

\section{References}

[1] N.A. Istomin, N.V. Zlobina, "Analiz institutsionalnogo vzaimodeystviya nauchno-issledovatelskogo sektora ekonomiki i biznessoobshchestva"// Nauchno-tekhnicheskiye vedomosti SPbGPU. Ekonomicheskiye nauki, № 10. 2017, pp. 38-46.

[2] G.I. Burdakova, Ye.V. Porvatkina, "Razvitiye innovatsionnogo predprinimatelstva na territorii operezhayushchego razvitiya na baze vysshego uchebnogo zavedeniya" // Innovatsionnaya ekonomika i promyshlennaya politika regiona (EKOPROM-2016): trudy mezhdunarodnoy nauchno-prakticheskoy konferentsii / pod red. d-ra ekon. nauk, prof. A.V. Babkina. - SPb.: Izd-vo Politekhn. un-ta, 2016, pp. 271-280.

[3] B. R. Klark, "Sozdaniye predprinimatelskikh universitetov: organizatsionnyye napravleniya transformatsii" / per. s angl. A. Smirnova; Gos. un-t - Vysshaya shkola ekonomiki. - M.: Izd. dom Gos. un-ta - Vysshey shkoly ekonomiki, 2011, 240 p.

[4] G. Itskovits, "Troynaya spiral. Universitety - predpriyatiya gosudarstvo. Innovatsii v deystvii": per. s angl. / pod red. A.F. Uvarova. Tomsk: Izd-vo Tomsk, gos. un-ta sistem upr. i radioelektroniki, 2010, $238 \mathrm{p}$.

[5] M. Unger, V. Polt, “«Treugolnik znaniy» mezhdu sferami nauki, obrazovaniya i innovatsiy: kontseptualnaya diskussiya"// Forsayt (Natsionalnyy issledovatelskiy universitet "Vysshaya shkola ekonomiki"). T. 11. № 2. 2017, p. 10-26.

[6] Poyasnitelnaya zapiska $\mathrm{k}$ proyektu rasporyazheniya pravitelstva Rossiyskoy Federatsii «Ob utverzhdenii Dolgosrochnogo plana kompleksnogo sotsialno-ekonomicheskogo razvitiya g. Komsomolskana-Amure».

[7] Proyekt programmy razvitiya opornogo universiteta FGBOU VO «Komsomolskiy-na-amure gosudarstvennyy tekhnicheskiy universitet» na 2017-2021 gg. ot 14 marta $2017 \mathrm{~g}$.

[8] Kontseptsiya razvitiya inzhenernogo obrazovaniya $\mathrm{v}$ Khabarovskom kraye/ pod red. A.M. Kondrakova. Moskva: Izd-vo Instituta mobilnykh obrazovatelnykh sistem, 2016, $136 \mathrm{p}$.

[9] Analiz sostoyaniya i problem razvitiya predprinimatelstva $\mathrm{v}$ nauchnotekhnicheskoy sfere Rossii / Pod redaktsiyey O. P. Molchanovoy. - M.: KDU, 2010, $204 \mathrm{p}$.
[10] R.S. Safin, Ye.L. Matukhin, "Obucheniye innovatsionnomu predprinimatelstvu $\mathrm{v}$ sisteme nepreryvnogo professionalnogo obrazovaniya"// Integratsiya obrazovaniya. Kazanskiy pedagogicheskiy zhurnal. 2012, 79-95 pp.

[11] V.A. Dubolazov, N.V. Neyelova, "Problemy podgotovki spetsialistov v oblasti innovatsionnogo predprinimatelstva"//Tezisy dokladov mezhdunarodnoy konferentsii «Formirovaniye professionalnykh predprinimatelskikh kompetentsiy molodezhi v protsesse obucheniya» M.: Izd. Dom «Sinergiya», 2014, 206-216 pp.

[12] I.V. Korchagina, K.V. Rogova, R.L. Korchagin, "Vovlecheniye rossiyskogo studenchestva $\mathrm{V}$ sovremennoye innovatsionnoye predprinimatelstvo"// Rossiyskoye predprinimatelstvo. T.18. №16. - M.: Izd-vo Kreativnaya ekonomika. 2017, 2301-2316 pp.

[13] I.A Bondareva, S.I. Kravchenko, A.V. Meshkov, "Osobennosti investitsionno-innovatsionnoy napravlennosti podgotovki studentov $\mathrm{v}$ tekhnicheskom vuze (na primere Donetskogo regiona) " // Nauchnotekhnicheskiye vedomosti SPbGPU. Ekonomicheskiye nauki. № 4 (223). 2015, 236-244 pp.

[14] A.N. Shichkov, A.A. Borisov, N.A. Kremleva, "Teoriya i praktika proyektirovaniya matematicheskoy modeli ekonomicheskoy sistemy inzhenernogo biznesa" // Nauchno-tekhnicheskiye vedomosti SPbGPU. Ekonomicheskiye nauki. № 10-4 (240). 2017, 207-216 pp.

[15] N.Ye. Yegorov, I.A. Babkin, "Kontseptualnaya model podgotovki spetsialistov $\mathrm{v}$ ramkakh gosudarstvenno-chastnogo partnerstva i kontseptsii troynoy spirali" // Nauchno-tekhnicheskiye vedomosti SPbGPU. Ekonomicheskiye nauki. № 6 (233). 2015. 216-221 pp.

[16] Pasport prioritetnogo proyekta "Vuzy kak tsentry prostranstva sozdaniya innovatsiy". Utverzhden prezidiumom Soveta pri Prezidente Rossiyskoy Federatsii po strategicheskomu razvitiyu i prioritetnym proyektam (protokol ot 25 oktyabrya 2016 g. № 9).

[17] Uchebnyye plany (bez GIA) napravleniy podgotovki bakalavrov 2016 goda nabora: «Prikladnaya informatika», «Elektronika i nanoelektronika», «Biotekhnicheskiye sistemy i tekhnologii», «Prikladnaya mekhanika», «Materialovedeniye i tekhnologii materialov», «Tekhnologiya transportnykh protsessov», «Innovatika». https://knastu.ru/media/files/cp (data obrashcheniya 08.08. 2017).

[18] N. N. Butryumova, Yu. N. Slepneva "Vovlecheniye studentov v innovatsionnoye predprinimatelstvo: opyt NIU VShE - Nizhniy Novgorod"//Vestnik SPbGU. Ser. 8. Menedzhment. Vyp. 1. 2016. S. 91-114.

[19] G. Shirokova, K. Bogatyreva, "Ot predprinimatelskikh namereniy k sozdaniyu biznesa: opyt rossiyskikh studentov"// Forsayt (Natsionalnyy issledovatelskiy universitet "Vysshaya shkola ekonomiki"). T. 11. № 3. 2017. 25-36 pp.

[20] Ye.I. Mikhaylova, "Universitet - intellektualnaya platforma innovatsionnogo-razvitiya Severo-Vostoka Rossii'// Vestnik mezhdunarodnykh organizatsiy: obrazovaniye, nauka, novaya ekonomika (Natsionalnyy issledovatelskiy universitet "Vysshaya shkola ekonomiki"). T. 8. № 1. 2013. 80-86 pp.

[21] Babkin, A.V., Karlina, E.P., Epifanova, N.Sh. Neural networks as a tool of forecasting of socioeconomic systems strategic development // Proceedings of the 28th International Business Information Management Association Conference - Vision 2020: Innovation Management, Development Sustainability, and Competitive Economic Growth, 2016. C. $11-17$ 